Katarzyna RADWAN ${ }^{1}$

Opiekun naukowy: Dorota WIĘCEK ${ }^{2}$

DOI: https://doi.org/10.53052/9788366249844.15

\title{
WYKORZYSTANIE NOWOCZESNYCH METOD KALKULACJI KOSZTÓW W WARUNKACH JEDNOSTKOWEJ I MALOSERYJNEJ PRODUKCJI
}

Streszczenie: W artykule przedstawione zostały rozwiązania z zakresu kalkulacji kosztów ze szczególnym uwzględnieniem uwarunkowań jednostkowej i małoseryjnej produkcji. Zasadniczą przesłanką podjęcia rozważań nad wspomnianym zagadnieniem jest konieczność wdrożenia w przedsiębiorstwach nowoczesnych metod z obszaru rachunkowości zarządczej, które umożliwiają racjonalizację podejmowanych decyzji.

Słowa kluczowe: kalkulacja kosztów, rachunek kosztów działań, rachunek kosztów działań sterowany czasem

\section{THE USE OF MODERN COST CALCULATION METHODS IN THE CONDITIONS OF UNIT AND SMALL PRODUCTION}

Summary: This article presents solutions in the field of cost calculation with particular emphasis on the conditions of unit and small-lot production. The main premise for considering the above-mentioned issue is the necessity to implement modern management accounting methods in enterprises, which enable rationalization of decisions taken.

Keywords: cost calculation, Activity-Based Costing, Time-Driven Activity-Based Costing

\section{Wprowadzenie}

Jednym z elementów skutecznego zarządzania przedsiębiorstwem jest umiejętne wdrożenie i realizacja rachunku kosztów dostosowanego do potrzeb danej organizacji [1].

\footnotetext{
1 Akademia Techniczno-Humanistyczna w Bielsku Białej, Wydział Budowy Maszyn i Informatyki, Kierunek: Zarządzanie i Inżynieria Produkcji, katarzynaradwan8@gmail.com

${ }^{2}$ dr inż., Akademia Techniczno-Humanistyczna w Bielsku Białej, Wydział Budowy Maszyn i Informatyki, Katedra Inżynierii Produkcji, dwiecek@ath.bielsko.pl
} 
Możliwość przeprowadzenia i analiza najbardziej kosztochłonnych sfer działalności przedsiębiorstwa jest kluczową zdolnością zarządczą świadczącą o skuteczności zarządzania [2]. Zarządzanie powinno być oparte na dobrze funkcjonujących systemach informacji, w tym również informacji o kosztach. Dynamika rynku wymaga znacznej elastyczności w dostosowaniu do warunków jakie na nim panują. $\mathrm{Z}$ tego powodu informacje o kosztach dostarczanych przez tradycyjne modele rachunku kosztów, mogą więc okazać się nieadekwatne do rzeczywistych potrzeb decyzyjnych. [3] Niniejszy artykuł jest poświęcony prezentacji istoty koncepcji zarządzania kosztami z wykorzystaniem nowoczesnych metod kalkulacji kosztów w warunkach jednostkowej i małoseryjnej produkcji.

\section{Zasobowy rachunek kosztów - zasadniczy krok do wdrożenia nowoczesnych metod kalkulacji kosztów}

Na dokładność wszelkich późniejszych obliczeń, jako pierwszy wpływa element zasobów [4]. Metodą kalkulacji wychodzącą poza tradycyjne rachunki kosztów jest zasobowy rachunek kosztów, który koncentruje się na kosztach zasobów. Ponadto pozwala na lepszą kontrolę posiadanych zasobów i ich kosztów niż tradycyjne metody kalkulacji [5]. W ramach poszczególnych miejsc powstawania kosztów najpierw definiowane powinny być pule wartości (Tabela 1) [4].

Tabela 1. Specyfika zasobów

\begin{tabular}{|c|c|}
\hline \multicolumn{2}{|l|}{ ZASOBY } \\
\hline Nazwa zasobu & Wartośćc \\
\hline Pracownicy nadzoru & $15000,00 \mathrm{zł}$ \\
\hline Pracownicy obsługi magazynowej & $10000,00 \mathrm{zł}$ \\
\hline Pracownicy sprzedaży & $15000,00 \mathrm{zl}$ \\
\hline Pracownicy produkcyjni & $50000,00 \mathrm{zł}$ \\
\hline Powierzchnia produkcyjna & $64000,00 \mathrm{zł}$ \\
\hline Powierzchnia magazynowa & $10000,00 \mathrm{zf}$ \\
\hline Powierzchnia biurowa & $15000,00 \mathrm{zł}$ \\
\hline Wyposażenie & $8000,00 \mathrm{zt}$ \\
\hline Maszyny produkcyjme & $63000,00 \mathrm{zł}$ \\
\hline RAZEM & $250000,00 \mathrm{zt}$ \\
\hline
\end{tabular}

Następnie do puli zasobów przypisywane są odpowiednie konta kosztów rodzajowych stanowiące analitykę dla zasobów (Tabela 2) [4].

Tabela 2. Układ rodzajowy kosztów

\begin{tabular}{|l|l|r|}
\hline \multicolumn{1}{|c|}{ Nazwa kosztu } & \multicolumn{1}{|c|}{ Szczegóły kosztu } & \multicolumn{1}{c|}{ Wartośćć } \\
\hline Amortyzacja & Odpisy amortyzacyjne środków trwałych oraz wartości niematerialnych i prawnych & $34000,00 \mathrm{zt}$ \\
\hline Zużycie materiałów i energii & Wartość materiałów wydanych z magazynu oraz koszty energii & $101000,00 \mathrm{zf}$ \\
\hline Usługi obce & Koszty usług i robót wykonywanych przez zewnętrzne podmioty na rzecz firmy & $12000,00 \mathrm{zt}$ \\
\hline Podatki i opłaty & Koszty związane z zapłatą podatków i opłat dotyczące działalności & $9000,00 \mathrm{zl}$ \\
\hline Wynagrodzenia & Koszty wynagrodzenia pieniężnego lub ekwiwalenty dla pracowników w kwotach brutto & $80000,00 \mathrm{zz}$ \\
\hline Świadczenia na rzecz pracowników & Koszty stanowiące narzuty na wynagrodzenia & $10000,00 \mathrm{zt}$ \\
\hline Pozostałe & Koszty nieujęte w poprzednich kontach (np. koszty reklamy) & $4000,00 \mathrm{zf}$ \\
\hline \multicolumn{2}{|l|}{ RAZEM } & $\mathbf{2 5 0 0 0 0 , 0 0 ~ z z}$ \\
\hline
\end{tabular}


Wśród podstawowych zalet zasobowego rachunku kosztów wyróżnić należy uzyskanie podstawy do wdrożenia koncepcji rachunku kosztów działań, przejrzystą ewidencję kosztów posiadanych zasobów oraz ścisłą kontrolę kosztów na poziomie posiadanych zasobów (Tabela 3) [6].

Tabela 3. Macierz zasobów i kosztów rodzajowych

\begin{tabular}{|l|c|c|c|c|c|c|c|c|c|}
\cline { 2 - 12 } & & & & & & & & \\
\hline
\end{tabular}

\section{Nowoczesne metody kalkulacji kosztów}

Informacje o kosztach muszą dotyczyć wielu płaszczyzn funkcjonowania [7]. Tradycyjny rachunek kosztów nie wystarcza do ukazania związków przyczynowoskutkowych pomiędzy kosztami a obiektami, które mają lub mogą mieć znaczenie z punktu widzenia podejmowania decyzji menedżerskich [8]. W celu podniesienia efektywności operacyjnej przedsiębiorstwa, potrzebne są nie tylko informacje o nośnikach kosztów, ale także szczegółowe informacje niefinansowe mówiące o przyczynach powstawania kosztów nazywane czynnikami kosztotwórczymi [9].

\subsection{Rachunek kosztów działań ABC (ang. Activity Based Costing)}

$\mathrm{W}$ rachunku $\mathrm{ABC}$ to działania postrzegane są jako miejsce przypisywania kosztów. Idea rachunku kosztów działań ABC dotyczy sposobu rozliczania kosztów pośrednich na produkty w przekroju kosztów działań związanych z ich wytwarzaniem, a nie w przekroju miejsc powstawania kosztów (Rysunek 1) [10].

Pierwszym etapem wdrożenia systemu rachunku kosztów ABC jest dokładne rozpoznanie działań jakie mają miejsce w konkretnym przedsiębiorstwie. Kolejny krok polega na zdefiniowaniu działań i wartości przypisanych kosztów do poszczególnych działań, czyli określenie nośników kosztów. Następną fazą jest ustalenie kosztów wyodrębnionych działań. Proces ten wymaga rozliczenia na działania kosztów ewidencjonowanych na kontach bezpośrednio na podstawie dowodów źródłowych i pośrednio na podstawie nośników kosztów zasobów. Czwarty krok stanowi rozliczenie kosztów pośrednich poszczególnych działań na produkty [11]. 


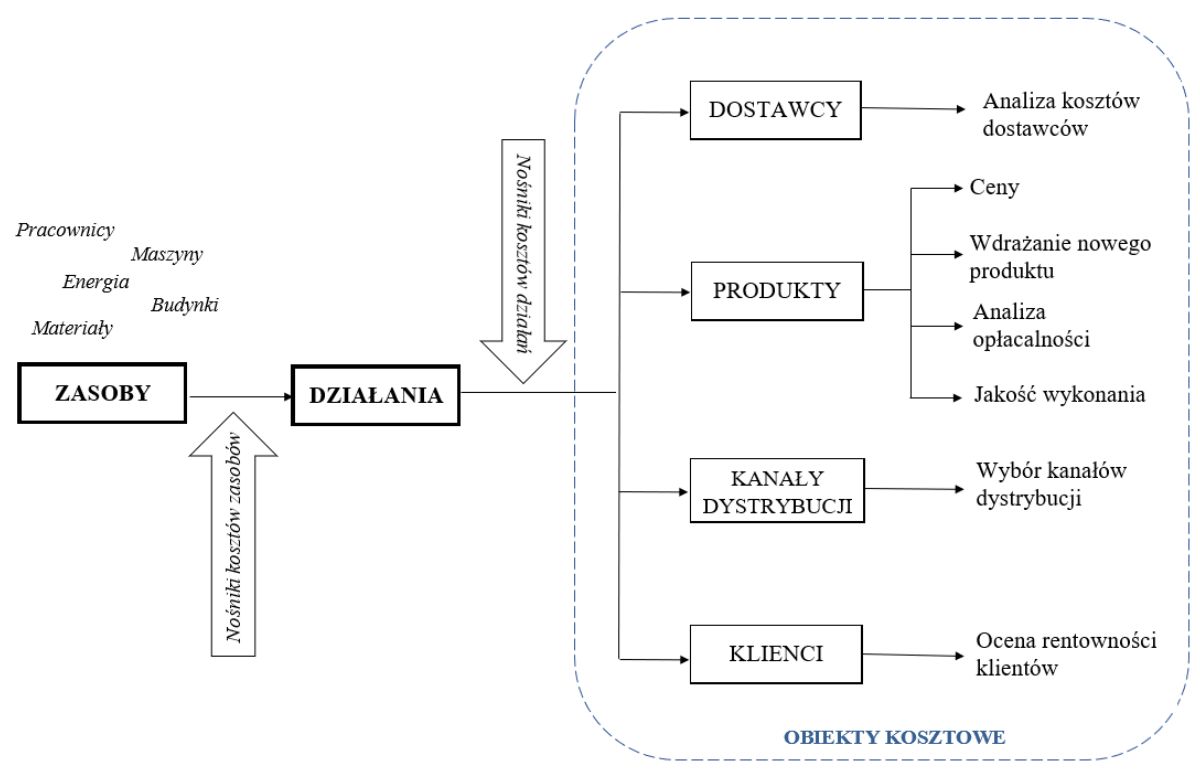

Rysunek 1. Kalkulacja wedtug kosztów dziatań

\subsection{Rachunek kosztów działań sterowany czasem TDABC (ang. Time-Driven Activity Based Costing)}

Rachunek kosztów działań sterowany czasem jest narzędziem budującym schemat kosztów zależny od czasu trwania procesu [2]. Konstrukcja systemu ABC sterowanego czasem wymaga wykonania sekwencji dobrze zdefiniowanych kroków [12]. W TDABC pojawia się uproszczenie w podejściu do kalkulacji kosztów. Podejście to zaleca przypisanie kosztów zasobów bezpośrednio do obiektów kosztowych, poprzez obliczenie w pierwszej kolejności zdolności produkcyjnych, a następnie oszacowaniu popytu obiektów kosztowych na zdolności produkcyjne [2]. Zastosowane we wspomnianym rachunku równania czasowe składają się ze zmiennych [2]. Cechą odróżniająca oba rachunki jest sposób rozliczania kosztów na obiekty (Rysunek 2).
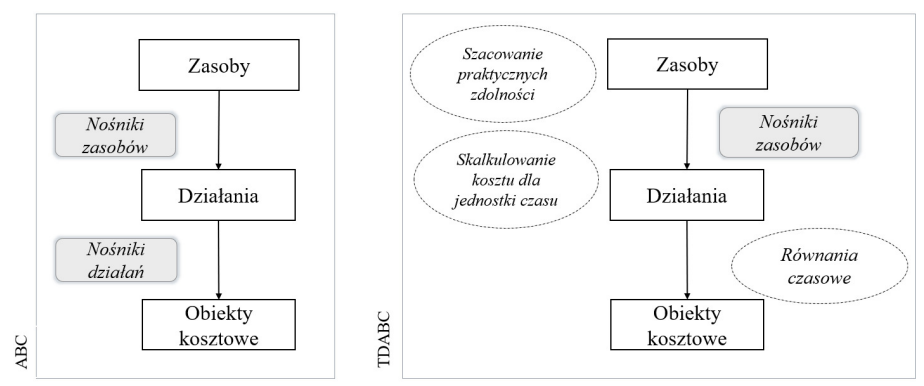

Rysunek 2. Porównanie klasycznego rachunku kosztów działań (ABC) i rachunku sterowanego czasem (TDABC) 
W rachunku kosztów działań dokonuje się kalkulacji kosztów pośrednich na produkty wykorzystując dwie grupy nośników kosztów, czyli nośniki kosztów zasobów i nośniki kosztów działań. W rachunku kosztów działań sterowanym czasem kalkulacja realizowana jest tylko w oparciu o jeden rodzaj nośników kosztów odnoszący się do czasu trwania [13].

\section{Przykład praktycznego wykorzystania nowoczesnych metod rachunku kosztów do kalkulacji kosztów produkcji małoseryjnej}

W wyniku przeprowadzenia wcześniejszych badań można stwierdzić, że oba typy rachunków - ABC i TDABC, są skutecznymi narzędziami do ewidencji kosztów, ale także do symulacji kosztów na potrzeby planowania kosztów. Poprzednie badania dowiodły, że rachunek TDABC jest skuteczniejszy niż ABC, gdy identyfikowalność zasobów z czynnościami jest wysoka, podczas gdy ABC jest dokładniejsze, gdy czynności są bardziej identyfikowalne z produktami, niezależnie od poziomu identyfikowalności zasobów do czynności.

\subsection{Wykorzystanie TDABC na przykładzie procesu zaopatrzenia}

Optymalizacja w zakresie kosztów zaopatrzenia, w tym możliwość sterowania kosztem w czasie, jest kluczowym elementem wpływającym na tempo uzyskania przychodu. Ze względu na aktualną sytuację związaną $\mathrm{z}$ przemianami spowodowanymi pandemią COVID-19 na świecie i drastycznymi podwyżkami cen i kosztów, zdecydowano się na analizę procesu zaopatrzenia dla produkcji małoseryjnej. W wyniku analizy ponoszonych kosztów, przyjęto, że całkowite koszty wydziału wynoszą 20000 zł miesięcznie. Schemat procesu zaopatrzenia w materiał przedstawiono na rysunku (Rysunek 3).

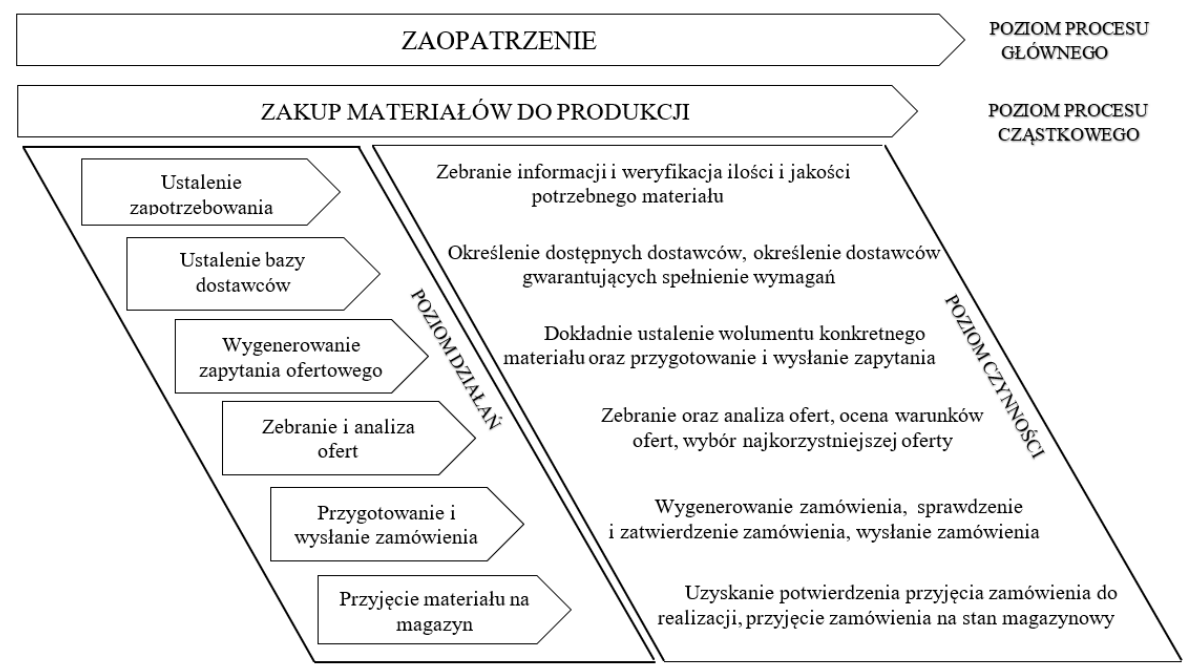

Rysunek 3. Porównanie klasycznego rachunku kosztów działań (ABC) i rachunku sterowanego czasem (TDABC) 
Założono, że wydział zatrudnia 3 pracowników. Każdy z nich pracuje przeciętnie 20 dni w miesiącu. Wynagrodzenie otrzymują za pracę 8 godzin dziennie. Wynika $\mathrm{z}$ tego, że każdy pracownik przebywa w pracy przez około 160 godzin w miesiącu, co daje 9600 minut. W wyniku analizy stwierdzono, że pracownicy spędzają w przybliżeniu 90 minut dziennie na przerwach i spotkaniach. W związku z tym praktyczna zdolność produkcyjna każdego pracownika wynosi około 7800 minut miesięcznie. Biorąc pod uwagę ilość pracowników wydziału, można stwierdzić, że wydział dysponuje praktyczną zdolnością produkcyjną 23400 minut. Jednostkowy koszt zapewnienia zdolności produkcyjnych można obliczyć następująco:

$$
K_{j z p}=\frac{K_{z p}}{T_{z p}}=\frac{20000[\mathrm{z}]}{23400[\mathrm{~min}]}=0,85 \frac{\mathrm{zł}}{\mathrm{min}}
$$

gdzie:

$K_{j z p}-$ jednostkowy koszt zdolności produkcyjnych,

$K_{z p}-$ koszt zapewniania zdolności produkcyjnych,

$T_{z p}$ - praktyczna zdolność produkcyjna.

Drugie oszacowanie konieczne w modelu TDABC dotyczy zdolności produkcyjnych. Istotnym jest wyznaczenie sumy czasu potrzebnego dla poszczególnych działań i w konsekwencji dla procesu. W tym celu wymagane jest zidentyfikowanie ilości wykonania danej czynności w skali czasu, czyli liczbę nośników kosztów i czasu potrzebnego dla konkretnego poddziałania. W niniejszym przykładzie, dla uproszczenia obliczeń, przyjęto tylko jeden wariant ze stałymi czasami. Kolejnym krokiem było obliczenie stawek nośników kosztów (Tabela 4).

Tabela 4. Stawki nośników kosztów w TDABC

\begin{tabular}{|c|c|c|}
\hline DZIALANIA & $\begin{array}{c}\text { CZAS JEDNOSTKOWY } \\
\text { (w minutach) }\end{array}$ & $\begin{array}{c}\text { STAWKA NOŚNIKA KOSZTóW } \\
\text { (w zl) }\end{array}$ \\
\hline ustalenie zapotrzebowania & 35 & 29,75 \\
\hline ustalenie dostawców & 20 & 17,00 \\
\hline wvgenerowanie zapvtania ofertowego & 5 & 4.25 \\
\hline zebranie i analiza ofert & 55 & 46,75 \\
\hline przvgotowanie i wvslanie zamówienia & 20 & 17,00 \\
\hline przviecie materialu & 10 & 8.50 \\
\hline
\end{tabular}

Z analizy wynika, że 92,31\% praktycznej zdolności produkcyjnej zostało produktywnie wykorzystanych w pracy (Tabela 6). Zgodnie z poniższym wzorem:

gdzie:

$$
Z P_{w}=\frac{T_{w z p}}{T_{z p}}=\frac{21600[\mathrm{~min}]}{23400[\mathrm{~min}]} \times 100 \%=92,31 \%
$$

$Z P_{w}$ - wykorzystane zdolności produkcyjne,

$T_{w z p}$ - czas wykorzystywania zdolności produkcyjnych,

$T_{z p}$ - praktyczna zdolność produkcyjna.

Różnica pomiędzy praktyczną zdolnością produkcyjną, a przeciętnym czasem działań wynosząca 1800 minut przeznaczona jest na inne prace zlecone przez przełożonego (Tabela 5). 
Tabela 5. Koszty realizacji działań według TDABC

\begin{tabular}{|c|c|c|c|c|}
\hline \multirow[t]{2}{*}{ DZIALANIA } & $\begin{array}{l}\text { CZAS JEDNOSTKOWY } \\
\text { (w minutach) }\end{array}$ & $\begin{array}{l}\text { LICZBA NOŚNIKÓW } \\
\text { KOSZTÓW }\end{array}$ & $\begin{array}{l}\text { CALKOWITY CZAS } \\
\text { (w minutach) }\end{array}$ & $\begin{array}{c}\text { PRZYPISANY KOSZT } \\
(\mathrm{w} \mathrm{zl})\end{array}$ \\
\hline & 1 & 2 & $3=1 \times 2$ & $4=3 \times 0,85 \mathrm{zt} / \mathrm{min}$ \\
\hline ustalenie zapotrzebowania & 35 & 250 & 8750 & 7437,50 \\
\hline ustalenie dostawców & 20 & 160 & 3200 & 2720,00 \\
\hline wygenerowanie zapytania ofertowego & 5 & 200 & 1000 & 850,00 \\
\hline zebranie $i$ analiza ofert & 55 & 130 & 7150 & 6077,50 \\
\hline przygotowanie i wysłanie zamówienia & 20 & 50 & 1000 & 850,00 \\
\hline $\begin{array}{l}\text { przyjęcie materiału } \\
\end{array}$ & 10 & 50 & 500 & 425,00 \\
\hline $\begin{array}{l}\text { wykorzystane zdolności produkcyjne } \\
92,31 \%\end{array}$ & $\mathrm{x}$ & $\mathrm{x}$ & 21600 & 18360,00 \\
\hline $\begin{array}{c}\text { niewykorzystane zdolności } \\
\text { produkcyjne } 7,69 \%\end{array}$ & $\mathrm{x}$ & $\mathrm{x}$ & 1800 & 1640,00 \\
\hline
\end{tabular}

Powyższe obliczenia dowiodły słuszność zastosowania rachunku kosztów działań sterowanego czasem w procesach pomocniczych.

\subsection{Zastosowanie rachunku kosztów działań ABC do kalkulacji kosztów produkcji jednostkowej i małoseryjnej $z$ wykorzystaniem zasobowego rachunku kosztów}

Ideą rachunku kosztów ABC jest powiązanie w pierwszej kolejności zasobów z działaniami, a w drugiej - działań z produktem lub innymi obiektami kosztowymi. W celu wyodrębnienia działań w ramach etapu pierwszego przeprowadzono analizę polegającą na rozpatrywaniu czynności koniecznych do wykonania wyrobów. W wyniku tej analizy nastąpiło zidentyfikowanie wszystkich działań (Rysunek 4).

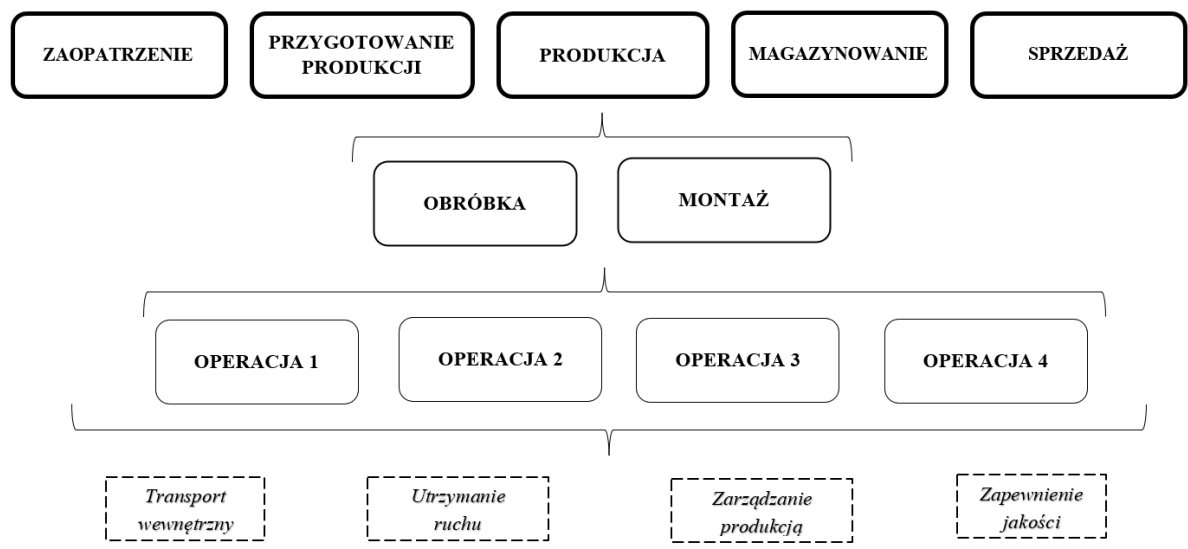

Rysunek 4. Struktura przebiegu procesu produkcyjnego

Określenie kosztów procesów jest jednym z najważniejszych zagadnień analizy procesu produkcyjnego. Na podstawie powyższego schematu można wyodrębnić działania główne, które generują wartość dodaną do realizowanego procesu oraz działania pomocnicze, głównie związane $\mathrm{z}$ przepływem informacji. Macierz procesów i zasobów przedstawia rysunek (Tabela 6). 
Tabela 6. Macierz procesów i zasobów

\begin{tabular}{|c|c|c|c|c|c|c|c|c|c|c|}
\hline & 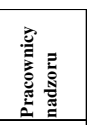 & 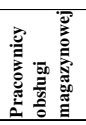 & 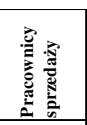 & 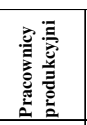 & 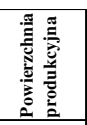 & 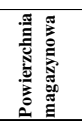 & 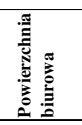 & 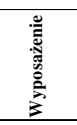 & 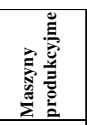 & \\
\hline Zaopatrzenie & $4500 \mathrm{zt}$ & $3500 \mathrm{zt}$ & & $3000 \mathrm{zt}$ & $2000 \mathrm{zt}$ & & $5000 \mathrm{zł}$ & $2000 \mathrm{zf}$ & & $20000 \mathrm{~d}$ \\
\hline \begin{tabular}{|l} 
Przygotowanie \\
produkcji
\end{tabular} & $3000 \mathrm{zt}$ & & $4500 \mathrm{zf}$ & $2000 \mathrm{zt}$ & & & $2000 \mathrm{zf}$ & $500 \mathrm{zt}$ & & $12000 \mathrm{z}$ \\
\hline Transport wewnętrzny & $1000 \mathrm{zf}$ & $2500 \mathrm{zf}$ & & $3000 \mathrm{zt}$ & $21000 \mathrm{zt}$ & $4000 \mathrm{zf}$ & & $1000 \mathrm{zf}$ & & $32500 \mathrm{zl}$ \\
\hline Utrzymanie ruchu & & & & $1000 \mathrm{zf}$ & $1000 \mathrm{zt}$ & & & $1000 \mathrm{zf}$ & $11000 \mathrm{zt}$ & 14000 zt \\
\hline $\begin{array}{l}\text { Produkcja i zarządzanie } \\
\text { produkcją }\end{array}$ & $5000 \mathrm{zt}$ & $1000 \mathrm{zf}$ & & $37000 \mathrm{zt}$ & $33000 \mathrm{zt}$ & & $5000 \mathrm{zt}$ & $2000 \mathrm{zt}$ & $49000 \mathrm{zt}$ & $132000 \mathrm{zt}$ \\
\hline Zapewnienie jakości & $1000 \mathrm{zt}$ & & $1500 \mathrm{zf}$ & $4000 \mathrm{zt}$ & $3000 \mathrm{zf}$ & & $2500 \mathrm{zt}$ & $500 \mathrm{zt}$ & & $12500 \mathrm{zt}$ \\
\hline Magazynowanie & $2000 \mathrm{zt}$ & $2500 \mathrm{zt}$ & & & $2000 \mathrm{zf}$ & $6000 \mathrm{zt}$ & & $500 \mathrm{zt}$ & & 13000 zt \\
\hline \multirow[t]{2}{*}{ Sprzedażi wysyłka } & & $500 \mathrm{zt}$ & $10000 \mathrm{zf}$ & & & $1000 \mathrm{zf}$ & $1500 \mathrm{zt}$ & $1000 \mathrm{zf}$ & & 14000 z \\
\hline & $16500 \mathrm{dt}$ & 10000 zt & $16000 \mathrm{zt}$ & $50000 \mathrm{zt}$ & $62000 \mathrm{zt}$ & 11000 zt & 16000 t & $8500 \mathrm{zt}$ & $60000 \mathrm{zt}$ & \\
\hline
\end{tabular}

W celu wykonania analizy procesowej i precyzyjnej identyfikacji procesów do budowy modelu ABC przydatne jest zastosowanie zasobowego rachunku kosztów. Koszty dla wyrobu mogą zostać pozyskane z arkusza rozliczeniowego. Przykładowa macierz kosztów rodzajowych i procesów została zaprezentowana poniżej (Tabela 7).

Tabela 7. Macierz kosztów rodzajowych i procesów

\begin{tabular}{|c|c|c|c|c|c|c|c|c|c|}
\hline & 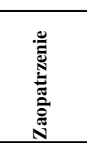 & 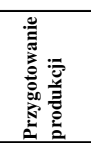 & 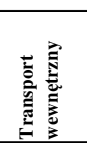 & 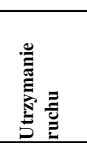 & 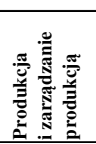 & 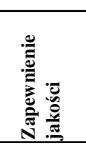 & 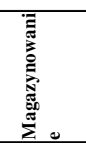 & 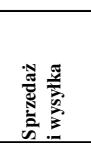 & \\
\hline Amortyzacja & $3500 \mathrm{zł}$ & $1000 \mathrm{zf}$ & $9500 \mathrm{zf}$ & $2000 \mathrm{zl}$ & $14000 \mathrm{zł}$ & & $4000 \mathrm{zf}$ & & $34000 \mathrm{zt}$ \\
\hline \begin{tabular}{|l|}
$\begin{array}{l}\text { Zużycie materiałów } \\
\text { i energii }\end{array}$ \\
\end{tabular} & $5000 \mathrm{zł}$ & $4500 \mathrm{zł}$ & $16000 \mathrm{zt}$ & $3000 \mathrm{zf}$ & $56500 \mathrm{zł}$ & $6000 \mathrm{zt}$ & $3000 \mathrm{zt}$ & $7000 \mathrm{zt}$ & $101000 \mathrm{zl}$ \\
\hline Usługi obce & $1000 \mathrm{zł}$ & $1000 \mathrm{zf}$ & & $3000 \mathrm{zf}$ & $6000 \mathrm{zł}$ & $1000 \mathrm{zł}$ & & & $12000 \mathrm{zt}$ \\
\hline Podatki i opłaty & $1500 \mathrm{zł}$ & & $1000 \mathrm{zf}$ & & $5000 \mathrm{zt}$ & $500 \mathrm{zł}$ & & $1000 \mathrm{zt}$ & 9000 at \\
\hline Wynagrodzenia & $7500 \mathrm{zt}$ & $5000 \mathrm{zł}$ & $5000 \mathrm{zf}$ & $4000 \mathrm{zl}$ & $47000 \mathrm{zł}$ & $3500 \mathrm{zf}$ & $4000 \mathrm{zt}$ & $4000 \mathrm{zt}$ & $80000 \mathrm{zt}$ \\
\hline \begin{tabular}{|l|} 
Świadczenia na \\
rzecz pracowników
\end{tabular} & $1000 \mathrm{zł}$ & $500 \mathrm{zf}$ & $1000 \mathrm{zf}$ & $1000 \mathrm{zł}$ & $2500 \mathrm{zł}$ & $1000 \mathrm{zł}$ & $1000 \mathrm{zł}$ & $2000 \mathrm{zt}$ & $10000 \mathrm{zt}$ \\
\hline \multirow[t]{2}{*}{ Pozostałe } & $500 \mathrm{zl}$ & & & $1000 \mathrm{zł}$ & $1000 \mathrm{zł}$ & $500 \mathrm{zł}$ & $1000 \mathrm{zf}$ & & 4000 zt \\
\hline & $20000 \mathrm{zt}$ & 12000 zt & $32500 \mathrm{zt}$ & 14000 zt & 132000 zt & 12500 zt & 13000 zt & 14000 zt & \\
\hline
\end{tabular}

W ramach etapu drugiego należy dokonać pomiaru kosztów według struktury wyodrębnionych działań (Tabela 8). 
Tabela 8. Drugi etap rachunku kosztów dziatań ABC

\begin{tabular}{|c|c|c|c|c|c|}
\hline LP. & DZIAŁANIA & $\begin{array}{c}\text { KLUCZ } \\
\text { ROZLICZENIOWY }\end{array}$ & $\begin{array}{c}\text { KOSZTY } \\
\text { DZIAŁAŃ }\end{array}$ & $\begin{array}{c}\text { LICZBA } \\
\text { DZIAKAŃ }\end{array}$ & $\begin{array}{c}\text { STAWKA } \\
\text { DZIAKANIA }\end{array}$ \\
\hline 1 & Zaopatrzenie & Liczba roboczogodzin & $20000,00 \mathrm{zł}$ & 100 & $200,00 \mathrm{zt}$ \\
\hline 2 & Przygotowanie produkcji & Liczba roboczogodzin & $12000,00 \mathrm{zf}$ & 120 & $100,00 \mathrm{zl}$ \\
\hline 3 & Transport wewnętrzny & Liczba transportów & $32500,00 \mathrm{zt}$ & 400 & $81,25 \mathrm{zt}$ \\
\hline 4 & Utrzymanie ruchu & Powierzchnia $\left(\mathrm{w} \mathrm{m}^{2}\right)$ & $14000,00 \mathrm{zł}$ & 80 & $175,00 \mathrm{zl}$ \\
\hline 5 & Produkcja i zarzadzanie produkcją & Liczba zleceń & $132000,00 \mathrm{zl}$ & 310 & $425,81 \mathrm{zl}$ \\
\hline 6 & Zapewnienie jakości & Liczba kontroli & $12500,00 \mathrm{zl}$ & 150 & $83,33 \mathrm{zl}$ \\
\hline 7 & Magazynowanie & Liczba dostaw & $13000,00 \mathrm{zt}$ & 100 & $130,00 \mathrm{zl}$ \\
\hline 8 & Sprzedaż i wysyłka & Liczba sztuk & $14000,00 \mathrm{zt}$ & 80 & $175,00 \mathrm{zl}$ \\
\hline \multicolumn{3}{|r|}{ RAZEM } & 250000,00 乙 & & \\
\hline
\end{tabular}

Koszty powinny być wprost proporcjonalne do ilości określonego działania, co obrazuje tabela 9 .

Tabela 9. Drugi etap rachunku kosztów działań ABC z uwzględnieniem liczby działań

\begin{tabular}{|c|c|c|c|c|}
\hline LP. & DZIALANIA & $\begin{array}{c}\text { STAWKA } \\
\text { DZIALANIA } \\
\end{array}$ & $\begin{array}{l}\text { LICZBA DZIAŁAŃ } \\
\text { DLA WYROBU X }\end{array}$ & $\begin{array}{l}\text { KOSZTY DZIALAŃ } \\
\text { DLA WYROBU X }\end{array}$ \\
\hline 1 & Zaopatrzenie & $200,00 \mathrm{zl}$ & 15 & $3000,00 \mathrm{zf}$ \\
\hline 2 & Przygotowanie produkcji & $100,00 \mathrm{zl}$ & 20 & $2000,00 \mathrm{zl}$ \\
\hline 3 & Transport wewnętrzny & $81,25 \mathrm{zl}$ & 40 & $3250,00 \mathrm{zt}$ \\
\hline 4 & Utrzymanie ruchu & $175,00 \mathrm{zl}$ & 15 & $2625,00 \mathrm{zt}$ \\
\hline 5 & Produkcja i zarządzanie produkcją & $425,81 \mathrm{zt}$ & 40 & $17032,26 \mathrm{zf}$ \\
\hline 6 & Zapewnienie jakości & $83,33 \mathrm{zt}$ & 30 & $2500,00 \mathrm{zf}$ \\
\hline 7 & Magazynowanie & $130,00 \mathrm{zt}$ & 40 & $5200,00 \mathrm{zt}$ \\
\hline 8 & Sprzedaż i wysyłka & $175,00 \mathrm{zł}$ & 20 & $3500,00 \mathrm{zt}$ \\
\hline
\end{tabular}

Zgodnie z etapem czwartym, koszty działań rozliczane są na produkty na podstawie zapotrzebowania produktu na określony rodzaj działań. Kartę kalkulacyjną dla urządzenia X przedstawia tabela 10.

Tabela 10. Karta kalkulacyjna urządzenia X

\begin{tabular}{|c|c|c|}
\hline & Wielkość produkcji [szt.] & 20 \\
\hline POZYCJE KALKULACYJNE & KOSZT CAŁKOWITY & KOSZT JEDNOSTKOWY \\
\hline 1. Koszty bezpośrednie & $110000,00 \mathrm{z}$ & $5500,00 \mathrm{z}$ \\
\hline a) materiały bezpośrednie & $20000,00 \mathrm{zł}$ & $1000,00 \mathrm{z}$ \\
\hline b) robocizna bezpośrednia & $90000,00 \mathrm{zł}$ & $4500,00 \mathrm{z}$ \\
\hline 2. Kostty wydziałowe & 39107,26 U & $1955,36 \mathrm{z}$ \\
\hline Zaopatrzenie & $3000,00 \mathrm{zł}$ & $150,00 \mathrm{z}$ \\
\hline Przygotowanie produkcji & $2000,00 \mathrm{zł}$ & $100,00 \mathrm{zl}$ \\
\hline Transport wewnętrzny & $3250,00 \mathrm{zł}$ & $162,50 \mathrm{z}$ \\
\hline Utrzymanie ruchu & $2625,00 \mathrm{zl}$ & $131,25 \mathrm{zl}$ \\
\hline Produkcja i zarządzanie produkcją & $17032,26 \mathrm{zt}$ & $851,61 \mathrm{z}$ \\
\hline Zapewnienie jakości & $2500,00 \mathrm{zł}$ & $125,00 \mathrm{zl}$ \\
\hline Magazynowanie & $5200,00 \mathrm{zł}$ & $260,00 \mathrm{z}$ \\
\hline Sprzedaż i wysyłka & $3500,00 \mathrm{zł}$ & $175,00 \mathrm{z}$ \\
\hline 3. Koszty wytworzenia [1+2] & 149107,26 d & $7455,36 \mathrm{z}$ \\
\hline
\end{tabular}




\section{Podsumowanie}

Zaproponowany sposób postępowania umożliwi szersze zastosowanie nowoczesnych metod kalkulacji kosztów działań w praktyce produkcyjnej. Artykuł ten może być istotnym przyczynkiem do podjęcia szerszych badań, których celem jest poddanie bardziej szczegółowej analizie zasad takiej integracji z kolejnymi metodami rachunku kosztów. Metoda rachunku kosztów działań lepiej oddaje powiązanie kosztów z przyczynami ich powstawania. Tak dokładna metoda określania kosztów nadaje się do zastosowania w warunkach produkcyjnych, w których wykonuje się wyroby w jednostkowej i małoseryjnej produkcji. Rachunek kosztów działań sterowany czasem jest narzędziem wynikającym z koncepcji ABC i pozwala na uzyskiwanie precyzyjnych informacji o kosztach działań oraz rentowności obiektów kosztowych, co potwierdza słuszność zastosowania wspomnianego rachunku do kalkulacji kosztów procesów pomocniczych. Wdrożenie nowoczesnych systemów rachunku kosztów daje możliwość stworzenia w przedsiębiorstwie zespołu instrumentów wspomagających zarządzanie, który opiera się na analizie działań.

\section{LITERATURA}

1. LEW G.: Integracja rachunku kosztów klienta $\mathrm{z}$ wybranymi metodami rachunkowości zarządczej, Humanities and Social Sciences, vol. XXI, 23 (3/2016), Rzeszów 2016.

2. DEMBIŃSKA I., MARZANTOWICZ Ł.: Wykorzystanie koncepcji TimeDriven Activity Based Costing w sterowaniu kosztami procesu zaopatrzenia, Zeszyty Naukowe Uniwersytetu Ekonomicznego w Katowicach Nr 348, Katowice 2018.

3. DZIADEK K.: Wybrane problemy wdrażania rachunku kosztów ABC w przedsiębiorstwach, Zeszyty Naukowe Instytutu Ekonomii i Zarządzania Politechniki Koszalińskiej, Koszalin 2010.

4. ZIELIŃSKI T.: Zasobowy rachunek kosztów - pierwszy krok do wdrożenia rachunku kosztów działań, MONITOR Rachunkowości i Finansów Nr 2, 2009.

5. ANDERS A., ŁACKI T.: Zasobowy rachunek kosztów w Niepublicznym Zakładzie Opieki Zdrowotnej, Controlling nr 7, INFOR, 2011.

6. ZIELIŃSKI T.: „As Easy As ABC” Zasobowy rachunek kosztów, Controlling i Rachunkowość Zarządcza nr 7, 2007.

7. LEW G., MARUSZEWSKA E., SZCZYPA P.: Rachunkowość zarządcza od teorii do praktyki, CeDeWu, Warszawa 2019.

8. ŚWIEBODA W.: Rachunek kosztów działań jako narzędzie w zarządzaniu przedsiębiorstwem, Zeszyty Naukowe Uniwersytetu Ekonomicznego w Katowicach, Katowice 2017.

9. ŚWIDERSKA G.: Controlling kosztów i rachunkowość zarządcza, Difin SA, Warszawa 2017.

10. KOTAPSKI R., KOWALAK R., LEW G.: Rachunek kosztów i rachunkowość zarządcza. Kompendium wiedzy, MARINA, Wrocław 2020.

11. WIĘCEK D., WIĘCEK D.: Wybrane zagadnienia z rachunku kosztów dla inżynierów, Wydawnictwo Naukowe Akademii Techniczno-Humanistycznej w Bielsku-Białej, Bielsko-Biała 2015. 
12. KAPLAN R., ANDERSON S.: Rachunek kosztów działań sterowany czasem, Wydawnictwo Naukowe PWN, Warszawa 2008.

13. ŚWIĘCICKA Z., JONEK-KOWALSKA I.: Możliwości zastosowania rachunku kosztów działań sterowanego czasem do kalkulacji kosztów projektów realizowanych w przedsiębiorstwie górniczym, Innowacje w zarządzaniu i inżynierii produkcji. T. 1. Pod red. Ryszarda Knosali, Oficyna Wydaw. Polskiego Towarzystwa Zarządzania Produkcją, Opole 2015. 
